\title{
THE
}

UNIVERSITY

University of Rhode Island

OF RHODE ISLAND

DigitalCommons@URI

Physics Faculty Publications

Physics

$11-1983$

\section{Woman Physicist Executed}

Gerhard Müller

University of Rhode Island, gmuller@uri.edu

Follow this and additional works at: https://digitalcommons.uri.edu/phys_facpubs

Terms of Use

All rights reserved under copyright.

\section{Citation/Publisher Attribution}

Müller, G. (1983). Woman physicist executed. Physics Today, 36(11), 11. doi: 10.1063/1.2915341

Available at: http://dx.doi.org/10.1063/1.2915341

This Article is brought to you for free and open access by the Physics at DigitalCommons@URI. It has been accepted for inclusion in Physics Faculty Publications by an authorized administrator of DigitalCommons@URI. For more information, please contact digitalcommons-group@uri.edu. 


\section{Physics Today}

\section{Woman physicist executed}

Gerhard Müller

Citation: Physics Today 36(11), 11 (1983); doi: 10.1063/1.2915341

View online: http://dx.doi.org/10.1063/1.2915341

View Table of Contents:

http://scitation.aip.org/content/aip/magazine/physicstoday/36/11?ver=pdfcov

Published by the AIP Publishing

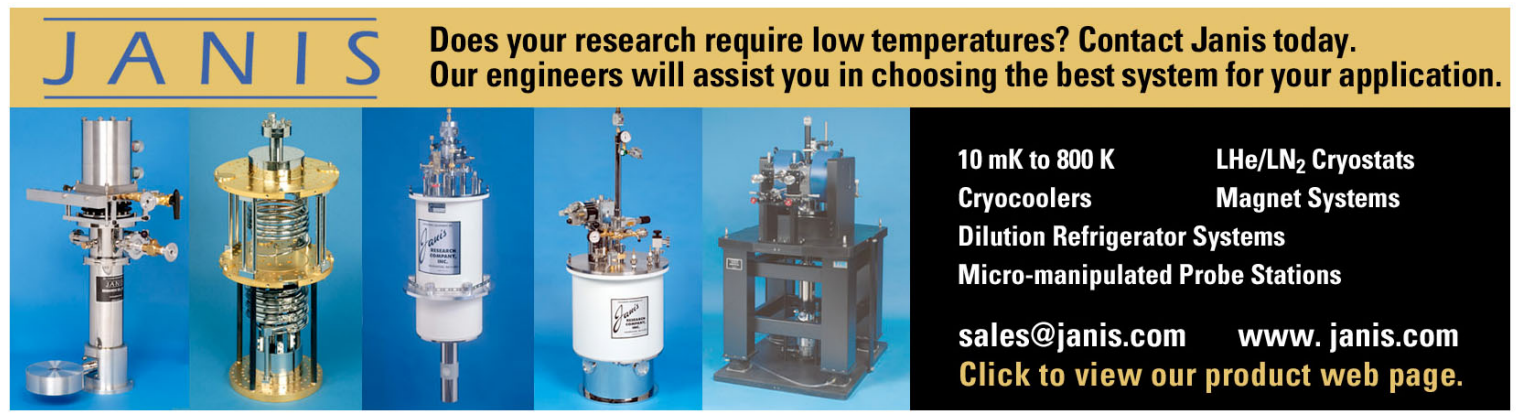




\section{axtipend}

\section{Woman physicist executed}

On 27 December 1981 Ginous Mahmoudi, the foremost woman physicist of Iran, was executed by a firing squad in Tehran. Her crime: She was an active member of the Baha'i Faith, thus belonging to the largest religious minority of her country. ${ }^{1}$

Ginous Mahmoudi was a well-known scientist in Iran. She was assistant director and later director of the department of meteorology of Iran, supervising the research of atmospheric studies in that country. In fact, the department of meteorology was built by her dedicated service of 25 years. She was also the president of the Iranian School of Meteorology.

Her scientific activities were brought to an abrupt end after the revolution of 1978-79, when a systematic, government-backed campaign to eradicate the Baha'i Faith as an independent religion in Iran was launched. Ginous Mahmoudi was fired from her position. The authorities even demanded that she return all salary she had received during the past 25 years on the grounds that it was illegal for a Baha'i to be hired by the government. A similar fate befell her husband, Houshang Mahmoudi, a respected and loved television personality and the founder of a well-known secondary school in Tehran. In spite of their own hardships, the Mahmoudis opened their home to shelter Baha'i families who were driven from their homes and had lost all their possessions. This situation continued until October 1981, when the revolutionary guards came and looted the Mahmoudis' house. All their property was destroyed or carried away.

Houshang Mahmoudi was a member of the National Spiritual Assembly of the Baha'is of Iran. On 21 August 1980 he, along with the eight other members, were abducted by revolutionary guards during a meeting of the Assembly. They were led away at gunpoint, and they disappeared. No explanation was ever offered by the Iranian government. They are presumed dead. Ginous Mahmoudi became chairperson of the newly elected Assembly. Deprived of her job, her husband and her home, she traveled extensively throughout her country visiting Baha'i prisoners and their families and trying to alleviate the situation of those who had lost everything. She was well aware of the danger for her life.

Her preserverence and her courage were too great a challenge for those who were-and still are-determined to complete the deadly campaign against the Baha'is. On 13 December 1981 she and her colleagues on the Assembly were arrested and, two weeks later, executed without charges, trial, public statement or notice to their families. The government first denied, but finally conceded the executions. Their desecrated bodies were found, accidentally half-buried in the "infidel" section of the Moslem cemetery in Tehran. However, their bodies could not be claimed by their families until the authorities were paid one thousand tuman for each bullet used to kill them.

This report is based on testimonies made at the Congressional hearings of the Subcommittee on Human Rights and International Organizations of the Foreign Affairs Committee of the US House of Representatives, held on 25 May 1981, in Washington, D.C. and published in the Congressional Record. The prepared statements as submitted to the Subcommittee have been published in World Order 16 No. 3 (1982).

Gerhard MÜLler State University of New York 8/83 Stony Brook, New York

\section{Help for amateur scientists}

As an "amateur scientist," I would like to suggest a solution to the scientist or mathematician who is not part of the scientific establishment. As a physicist and mathematician, I have been doing completely independent research, free from peer pressure and independent of my livelihood in computer science with IBM Corporation.

The main advantage is, of course, the ability to speculate and imagine physical concepts and mathematical tools that would be impossible if a reputation had to be based on the norms of the mainstream. As an example, theories on the structure of space and on the

\section{The most} useful NIM Pulser

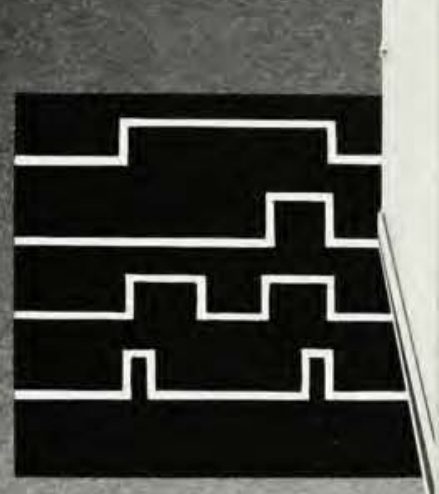
$\vdots$

BNC's popular Model 8010 Pulse Generator offers you no less than 8 modes of operation for only $\$ 840$.

Here they are:

1. Frequency Source or Oscillator that is continuously variable from $1 \mathrm{~Hz}$ to $50 \mathrm{MHz}$.

2. Delay Generator from $25 \mathrm{~ns}$ through 1 sec.

3. Double Pulser producing pulse pairs with continuously variable separation.

4. Gate or Width Generator from 20 ns through 1 sec.

5. Single Pulser with pushbutton initiation of a single pulse or single pulse pair.

6. Gateable Oscillator with pulse burst and clock synchronizing capabilities.

7. Triggerable Pulse Source which produces pulses when signalled.

8. Four-Output Pulser with ECL, NIM, Positive normal, and Positive complementary stimulus capabilities.

With the Model 8010 on your bench, you'll save both set-up and test time. And you may very well avoid the need to design additional circuitry or buy more equipment. Request our 8010 specification sheet or better yet call John Yee.

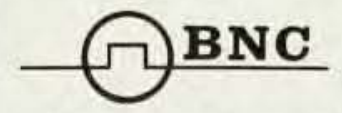

Berkeley Nucleonics Corporation 1198 Tenth Street

Berkeley, CA 94710

Phone (415) 527-1121 